Journal of Education and Teaching Learning (JETL)

Volume 4, Issue 1, January 2022

Journal Homepage:

http://pusdikra-publishing.com/index.php/jetl

\title{
Distance Learning Solutions During the Covid 19 Pandemic At Aceh Tamiang Islamic High School
}

\section{Muhammad Jailani', Alfiana Utama ${ }^{2}$ \\ 1,2Sekolah Tinggi Agama Islam Aceh Tamiang}

Corresponding Author : muhammadjailani@staiat.ac.id

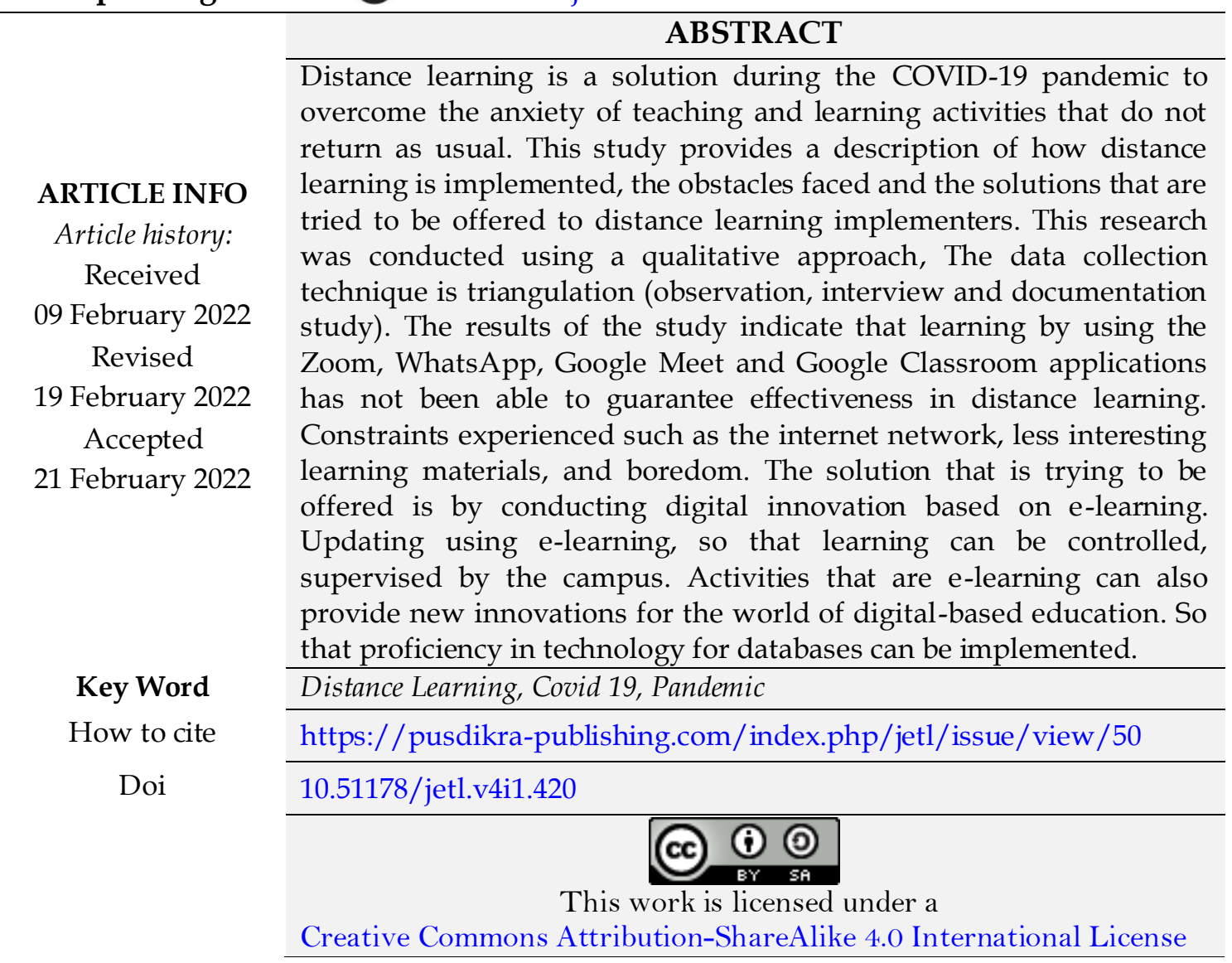

\section{PENDAHULUAN}

Pandemi COVID-19 yang terjadi telah menyebar secara cepat ke seluruh dunia, tidak terkecuali Indonesia. Pandemi ini telah memberikan dampak signifikan pada semua sektor kehidupan manusia seperti ekonomi, perdagangan, pariwisata, dan pendidikan. Dalam skala global, tercatat sebanyak 1.186.127.211 pelajar yang terdampak penutupan sekolah akibat COVID-19, di mana dampak tersebut berujung pada terganggunya proses belajar-mengajar secara luring, di Indonesia sendiri angka tersebut mencapai sebanyak 68.265.787 pelajar yang terkena dampak penutupan sekolah (Syah, 2020).

Selama COVID-19, kegiatan belajar mengajar secara tatap muka lumpuh total karena cepatnya penyebaran wabah. Hal tersebut membuat pemerintah 
mencari jalan keluar agar transfer ilmu tetap bisa terlaksana, meski tanpa bertatap muka. Sehingga satu-satunya opsi yang memungkinkan adalah dengan melaksanakan pembelajaran jarak jauh yang dilakukan dari rumah masing-masing mahasiswa dengan mengandalkan koneksi internet.

Pandemi COVID-19, suka atau pun tak suka telah memaksa kita untuk melakukan sesuatu diluar kebiasaan agar tetap dapat bertahan. Tak terkecuali dibidang Pendidikan yang tentu membutuhkan terobosan dan inovasi agar akses, ketersediaan dan proses pendidikan dapat berjalan dalam adaptasi kebiasaan baru (new normal). Pembelajaran Jarak Jauh (PJJ) merupakan salah satu alternatif kebijakan yang diambil untuk meminimalisir meluasnya kasus covid 19 sekaligus sebagai upaya dalam memutus mata rantai penyebarannya. Namun, kebijakannya ini tentu tidak mudah untuk diimplementasikan, karena berbagai keterbatasan baik yang disebabkan oleh kesiapan dan ketersediaan Infrastruktur teknologi maupun adaptasi kurikulum dan kemampuan guru sebagai fasilitator yang harus disesuaikan dengan kondisi terkini (Zainal, 2020).

Pembelajaran jarak jauh atau bisa disebut juga pembelajaran daring merupakan pembelajaran yang menggunakan jaringan internet dengan aksesibilitas, konektivitas, fleksibilitas, dan kemampuan untuk memunculkan berbagai jenis interaksi pembelajaran. Pada tataran pelaksanaannya pembelajaran jarak jauh (daring) memerlukan dukungan perangkat-perangkat mobile seperti smarphone atau telepon android, laptop, komputer, tablet, dan iphone yang dapat dipergunakan untuk mengakses informasi kapan saja dan dimana saja (Sri \& Husniyatus, 2020; Syah, 2020).

Pembelajaran jarak jauh dianggap sebagai solusi dalam keberlangsungan pembelajaran ditengah pandemi. Akan tetapi akses internet juga sering mengalami gangguan akibat tidak stabilnya jaringan di daerah masing-masing, dan juga sumber daya listrik yang masih belum maksimal untuk bisa menyala selama 24 jam (Nahdi et al., 2020). Akses listrik, koneksi internet merupakan tiga hal penting yang dibutuhkan untuk melakukan pembelajaran jarak jauh yang sifatnya daring. Masalah muncul manakala banyak yang mengeluhkan akses pada koneksi dan infrastruktur internet yang tidak merata di seluruh wilayah (Syaharuddin, 2020).

Tidak hanya dari segi fasilitas saja yang menjadi kendala dalam pembelajaran secara online, namun gangguan ternyata juga terjadi pada diri masing-masing peserta pembelajaran, mengapa tidak. Kesulitan memahami materi yang disampaikan dalam perkuliahan, kebosanan, mengantuk dan adanya aktifitas lain yang dilakukan mahasiswa seperti membuka aplikasiaplikasi medsos saat pembelajaran berlangsung (Jatiyasa, 2022). Selain masalah kepribadian yang kurang disiplin dari mahasiswa, tidak bisa kita 
kesampingkan pula menyoal ekonomi mahasiswa yang semakin mencekik dikarenakan keharusan membeli kuota paket data yang penggunaannya tinggi dimasa perkuliahan daring, hampir seluruh mahasiswa mengeluhkan pemakaian data yang boros, sehingga para orang tua harus merogoh kocek lebih dalam lagi (Abidin et al., 2020).

Pembelajaran jarak jauh di berbagai daerah memiliki pola masalah yang hampir rata-rata sama, interaksi sosial yang menurun, kebutuhan ekonomi, jaringan internet yang tidak stabil, konsentrasi peserta during yang terpecah belah. Sehingga perlu adanya solusi-solusi yang baik untuk lebih memaksimalkan pembelajaran sehingga mutu pendidikan masih dapat terjaga.

\section{METODE PENELITIAN}

Penelitian ini dilaksanakan di Sekolah Tinggi Agama Islam Aceh Tamiang (STAI-AT). Dengan tujuan melihat bagaimana proses pembelajaran jarak jauh yang terjadi selama pandemi covid-19. Objek data adalah kepada mahasiswa yang sedang melakukan keberlangsungan pembelajaran secara daring.

Metode penelitian yang digunakan dengan melakukan pendekatan kualitatif, metode penelitian ini merupakan metode yang berlandaskan pada filsafat post positivisme, digunakan untuk meneliti pada kondisi obyek yang alamiah. Tekhnik pengumpulan data yaitu dengan tri-anggulasi (observasi, wawancara dan studi dokumentasi). Perlu adanya juga pengecekan keabsahan data, kelengkapan data dan penarikan seluruh kesimpulan dari hasil penelitian yang dilakukan (Lexy Moleong, 2014; Sugiyono, 2016; Tobing, 2016).

\section{HASIL PENELITIAN DAN PEMBAHASAN}

\section{Hasil Penelitian}

\section{Implementasi Dan Solusi Pembelajaran Jarak Jauh Di Sekolah Tinggi Agama Islam Aceh Tamiang (STAI-AT)}

Selama pandemi berlangsung proses peralihan pembelajaran jarak jauh melalui rumah terus digalakkan untuk memutus mata rantai covid-19. Kebijakan perkuliahan daring ini dilakukan dengan menggunakan aplikasiaplikasi seperti zoom, google meet, google classroom dan whatshapp. Proses pembelajaran seperti absensi kehadiran, diskusi, presentasi hingga tanya jawab semuanya dilakukan lewat dunia maya. Setiap dosen dibebaskan untuk menentukan aplikasi mana yang akan digunakan selama proses perkuliahan.

Kehadiran-kehadiran aplikasi ini juga sebenarnya membantu dalam proses penyimpanan data, seperti google classroom yang memang semua data seperti hasil ujian, daftar hadir, soal-soal, tugas rutin dapat tersimpan. 
Penjadwalan untuk absensi juga lebih sistematis, para dosen bisa menyesuaikan jadwalnya untuk minggu-minggu berikutnya.

Beberapa dosen mengatakan lebih cenderung menggunakan zoom meeting dikarenakan dapat berinteraksi dengan mahasiswa sehingga menumbuhkan gairah untuk berdiskusi selayaknya di dalam ruangan kelas. Aplikasi zoom ini juga memberikan fitur-fitur yang lebih menarik, kejernihan kualitas gambar dan juga kejelasan suara. Akan tetapi aplikasi ini hanya memberikan kita free pemakaian hanya untuk 40 menit pemakaian saja. Sementara dalam sekali tatap muka daring itu kurang lebih 100 menit, sehingga aplikasi zoom ini tidak ramah untuk meyoal pendaan. Aplikasi zoom dan google meet memang memberikan kita wadah untuk bertatap muka dengan para mahasiswa, tetapi harus membutuhkan jaringan/koneksi yang stabil. Bila jaringan tidak baik, maka akan hanya memperlambat proses perkuliahan.

Dilematika proses pembelajaran dengan menggunakan whatsapp yaitu ketidak mampuan seorang dosen untuk mengontrol apakah mahasiswa tersebut sedang mengikuti proses pembelajaran dengan serius atau tidak, biasanya bila dilakukan presentasi para mahasiswa hanya memberikan pertanyaan-pertanyaan dengan teks, seharusnya dengan voicenote dapat membuat konsentrasi pada perkuliahan bertambah. Akan tetapi tidak begitu efektif juga, karena disaat yang lain melakukan presentasi kita sama sekali tidak mengetahui apa yang sedang mereka lakukan di rumah.

Kampus mencoba untuk terus berinovasi dengan para dosen-dosen yang ada, terus berkoordinasi agar proses pembelajaran lebih berdaya tarik, bagaimanapun kampus sebagai rumah ilmu tidak ingin selama pandemic mahasiswa justru semakin merosot pengetahuannya. Para dosen juga dilatih untuk lebih cakap dalam menggunakan aplikasi-aplikasi selama daring, dan juga dilatih untuk membuat tampilan powerpoint, video tutorial dan presentasi yang menarik Di Sekolah Tinggi Agama Islam Aceh Tamiang (STAI-AT).

Beberapa kampus juga melakukan hal yang sama, seperti mengadakan "Bakti Kampus" yaitu program untuk memudahkan interaksi dosen dengan mahasiswa, dan membuat pembelajaran daring agar lebih efekti dan efesien. Metode pembelajaran diantaranya e-learning dan pembuatan video tutorial. Adapun target yang dimiliki dalam metode pembelajaran ini adalah untuk meningkatkan keaktifan mahasiswa dan meningkatkan pemahaman mahasiswa terhadap materi yang disampaikan oleh dosen. Beberapa program telah dilaksanakan yaitu: membuat Google Classroom, membuat video tutorial, membuat desain powerpoint, dan membantu dosen menggunakan Zoom Meeting (Setyawati \& Harun, 3 C.E.). Dengan menggunakan video pembelajaran materi yang disampaikan menunjukkan 90\% mahasiswa 
memiliki motivasi belajar yang tinggi dalam belajar, dan dengan menggunakan video pembelajaran juga data menjadi alternatif untuk mahasiswa dapat belajar dan memahami dengan baik (Ammy, 2020).

\section{Kendala Pembelajaran Jarak Jauh Di Masa Pandemi Covid 19}

Walaupun berbagai solusi yang ditawarkan kepada kampus dalam pembelajaran di era pandemi ini begitu banyak dan alternatif, namun tidak dapat dipungkiri bahwa kendala yang dihadapai dalam melaksanakan pembelajaran pasti sudah dialami selama proses pembelajaran. Apalagi pembelajaran secara online/daring bukanlah murni kesiapan dari pihak kampus, mahasiswa dan dosen, melainkan karena adanya wabah yang mengharuskan pelaksanaan pembelajaran secara darurat.

Kendala yang dialami hampir secara keseluruhan mahasiswa dan dosen adalah masalah jaringan internet. Memang dibeberapa titik jaringan seperti 4G sudah mampu diakses, namun masih banyaknya mahasiswa yang mengalami kesulitan dalam mencari jaringan dikarenakan rumah mereka yang jauh dari jarak lokasi, dan masih tergolong daerah pedesaan. Mahasiswa harus lebih memutar otak mereka untuk berusahan mendapatkan jaringan yang stabil, sedikit banyaknya mereka justru izin tidak masuk kelas karena dengan kondisi jaringan yang tidak memungkinkan. Bahkan salah satu mahasiswa hampir $7 \mathrm{x}$ absen selama 1 semester hanya dikarenakan jaringan yang tidak baik.

Kendala berikutnya yang dialami mahasiswa adalah kejenuhan akan pembelajaran yang diberikan dosen mata kuliah kepada mereka, rasa-rasanya kurang ideal bila hanya memberikan daftar absen, mengirim bahan ajar dan mahasiswa diminta untuk belajar secara mandiri. Untuk seterusnya diberikan tugas yang harus dikerjakan setiap minggu. Walaupun aplikasi zoom dan google meet telah tersedia, namun bukanlah menjadi pilihan bagi para dosen untuk melakukan pembelajaran, ini dikarenakan penggunaan aplikasi seperti zoom ini memakan paket data yang begitu besar.

Konsentrasi menjadi tolak ukur apakah seseorang mampu menyerap apa yang disampaikan, apa yang di dengar dan dilihat olehnya, pada pembelajaran jarak jauh seperti saat ini, konsentrasi mahasiswa sudah pasti buyar, pasalnya ada banyak sekali mahasiswa yang justru melakukan aktivitas saat pembelajaran daring berlangsung, ada yang berkebun, memasak, berjualan dan membantu pekerjaan orang tua. Hal ini juga yang perlu disadari oleh mahasiswa bahwasanya tetap harus mengutamakan perkuliahan diatas segalanya.

Kendala yang dihadapi seperti terbatasnya layanan pembelajaran yang diberikan, Kurangnya pemahaman penggunaan aplikasi pembelajaran, dan 
kendala internet. Ini harus menjadi salah satu hal yang harus diperhatikan baik pemerintah, instansi kependidikan, pengajar dan Mahasiswa saat mempersiapkan dan melaksanakan pembelajaran online (Fikri et al., 2021). Kendala seperti ketersediaan media pembelajaran (ponsel, komputer, atau laptop), kurangnya penguasaan ilmu pengetahuan dan teknologi (iptek), kendala biaya pembelian paket internet (kuota), kendala waktu (kuota). (Dian Primasari \& Zulela, 2021). Hasil riset dari 300 mahasiswa yang dijadikan sampel pada penelitian, menunjukkan bahwa mahasiswa mengalami stres selama pembelajaran jarak jauh (Harahap et al., 2020). Bahkan (Supriyatno et al., 2020) dengna tidak berlebihan mengatakan dalam risetnya bahwa media elearning dapat meningkatkan kemampuan berpikir kritis siswa, pelaksanaan pembelajaran pun lebih efektif dan efesien.

Kendala-kendala yang dihadapi diatas perlu kiranya mendapat perhatian khusus, baik dari pihak kampus, kalangan dosen, pemerintah dan seluruh civitas akademika demi menunjang mutu pembelajaran yang sebenarnya telah menurun dikarenakan pandemi covid-19. Perlu adanya persiapan-persiapan yang lebih matang, perlu adanya kontrol saat pelaksanaan perkuliahan baik terhadap dosen terutama mahasiswa. Perlu adanya evaluasi bulanan terkait keberlangsungan peroses pembelajaran.

\section{Pembahasan}

Saat ini situasi di Indonesia sedang mengalami kondisi yag tidak jauh berbeda dengan Negara-negara tetangga yang lain. Virus Corona telah mengubah situasi yang kondusif menjadi situasi global yang mengguncang segala tatanan kehidupan. Dunia pendidikan juga dibuat kalang kabut sistem pembelajaran menjadi kacau karena Mahasiswa tidak diperbolehkan untuk tatap muka. Melihat situasi seperti ini kebijakan pemerintah tentang pembelajaran sangat diharapkan dapat menjembatani keadaan tersebut. Kebijakan pemerintah mengenai pembelajaran jarak jauh (daring) di masa pandemi Covid-19 dirasa oleh pemerintah sebagai solusi untuk menjembatani kegiatan proses belajar mengajar.

Dengan adanya kebijakan pembelajaran jarak jauh secara tidak langsung telah mengubah paradigma sistem pembelajaran konvensional yang semula tatap muka di kelas kemudian berubah menjadi secara virtual dan tidak bertemu langsung di kelas. e-learning menjadi pilihan solusi dalam menunjang kebijakan pembelajaran jarak jauh. e-learning adalah gabungan antara pembelajaran elektronik dan teknologi informasi. Beberapa kalangan justru menganggap penggunaan e-learning sebagai alternative pembelajaran yang tepat karena sistem e-learning tidak memiliki batasan akses, sehingga 
memungkinkan pembelajaran dapat dilakukan lebih banyak waktu, dan tidak memerlukan tatap muka mengingat social distancing dan kebijakan lain terkait protokol kesehatan yang telah ditetapkan oleh pemerintah. (Jamal, 2020) mengatakan dalam penelitiannya bahwa penerapan e-learning di SMK negeri 1 Tambelangan dapat dilakukan, ini dikarenakan kesipan dari murid, guru, infrastruktur, manajemen dan budaya sekolah.

Pembelajaran jarak jauh ternyata dapat meningkatkan partisipasi aktif dari Mahasiswa. Pada saat pembelajaran secara langsung biasanya partisipasi Mahasiswa sangat kecil, hanya beberapa orang saja yang mau berpartisipasi dalam pembelajaran. Berbeda saat pembelajaran jarak jauh, hampir semua Mahasiswa akan berpartisipasi aktif dalam proses belajar, karena mereka tidak merasa canggung atau mungkin kurang percaya diri. Pembelajaran dengan $e$ learning dapat membawa suasana baru dalam ragam pengembangan pembelajaran, terutama pada masa Pandemi COVID-19 yang sedang terjadi saat ini. Pemanfaatan e-learning dengan baik tentunya dapat meningkatkan hasil pembelajaran secara maksimal pada masa pandemi COVID-19 yang sedang melanda negeri ini. E-learning dapat mempermudah interaksi antara pebelajar atau peserta didik dengan bahan materi pelajaran, Guru/pengajar, dan antara sesama pebelajar/peserta didik (Sukanto, 2020).

(Indrayana \& Ali Sadikin, 2020) mengungkapkan bahwa ada beberapa poin positif yang ditemukan pada penerapan pembelaajran e-learning, diantaranya (1) Mahasiswa merasa tertarik dengan penerapan elearning. (2) penerapan e-learning memudahkan mahasiswa dalam mengikuti perkuliahan. (3) Penerapan e-learning dapat mencegah penularan covid-19 di kampus. Penerapan e-learning memiliki kendala bagi mahasiswa yang tinggal daerah terpencil. Penerapan e-learning membuat mahasiswa menjadi mandiri dan memiliki keberanian dalam mengemukakan pendapat. (Sakti \& Sulung, 2020) pada proses pembelajaran yang paling diminati mahasiswa adalah dengan menggunakan aplikasi zoom dan whatsapp, terjadi hal posistif yaitu meningkatnya motivasi baik guru/dosen juga siswa dan mahasiswa dalam mempergunakan media online dalam proses pembelajaran. (Sujarwo et al., 2020) Cara pandang siswa terhadap pembelajaran online berdampak positif di tengah pandemi covid-19, Di tengah pandemi covid-19, para siswa tertarik untuk menggunakan pembelajaran online yang dapat diakses secara fleksibel, di mana saja dan di mana saja. Aplikasi terbaik yang digunakan dosen dan mahasiswa adalah aplikasi WhatsApp.

Situsi yang seperti ini justru Dosen harus memiliki prinsip, skill dan trik yang harus dikuasai untuk mengatasi kendala-kendala sehingga pembelajaran jarak jauh memang benar-benar menjadi solusi terbaik dalam proses belajar 
mengajar secara daring. Pertama, pembelajaran daring jangan sampai menambah beban Dosen, mahasiswa dan orang tua, karena tujuannya adalah untuk memudahkan belajar. Kedua, mahasiswa diberi ugas belajar sewajarnya saja dengan instruksi yang jelas dan sesuai dengan tujuan belajar. Oleh karena itu Dosen sangat perlu untuk selalu berkomunkasi dengan mahasiswa maupun orang tua mahasiswa. Dalam sistem pembelajaran secara daring Dosen harus memberi stimulus yang baik, memberi respon, dan membuka ruang untuk berdialog secara demokratis sehingga mahasiswa nyaman dan betah berlamalama untuk mengikuti pembelajaran secara daring. Ketiga, jika ada waktu yang mendesak dapat memanfaatkan berbagai sumber yang tersedia di dunia maya. Prinsip yang keempat adalah fleksibel metode pembelajaran artinya metode harus menyesuaikan dengan karakteristik materi pembelajaran dan mahasiswa. Fleksibel di sini artinya fleksibel tempat yakni pembelajaran dapat berlangsung dimana saja (di rumah, di halaman, di masjid atau yang lainnya), fleksibel waktu artinya pembelajaran tidak harus tepat waktu seperti pembelajaran tatap muka di kelas. Biasanya pembelajaran daring waktunya lebih lama karena bias dengan video call, zoom meeting, webinar, teleconference, dan lain-lain. Prinsip yang kelima adalah pembelajaran daring merupakan bentuk personalisasi pembelajaran, sehingga diperlukan kesadaran yang serius untuk belajar dari para mahasiswa dan harus diimbangi oleh Dosen untuk selalu mengontrol pembelajaran mahasiswa secara berkala. Caranya dengan selalu memberikan stimulus kepada mahasiswa pada saat pembelajaran daring ini karena pada dasarnya pembelajaran ini memerlukan penerapan yang serius ditengah keterbatasan, kebijakan, maupun kebutuhan yang ada.

Kelas online darurat dioperasikan untuk sementara waktu tanpa desain kelas yang direncanakan tidak seperti pembelajaran online yang ada, baik Mahasiswa maupun Dosen mengalami kesulitan beradaptasi dengannya. Lembaga yang mengoperasikan pengajaran online harus mempertimbangkan dukungan yang dapat dengan mudah digunakan, efektif, dan mengatasi berbagai faktor kesulitan dari pembelajaran online seperti interaksi dengan mahasiswa dan orang tua atau wali mereka, infrastruktur yang dibutuhkan, kemampuan personel untuk mengoperasikan pembelajaran online, personil sekolah, dan umpan balik dari pembelajaran.

Selain penggunaan dari aplikasi-aplikasi pembelajaran diatas, perlu kiranya melakukan pemutakhiran dengan menggunakan e-learning, agar pembelajaran dapat di kontrol, diawasi oleh pihak kampus. Kegiatan yang bersifat e-learning juga dapat memberikan inovasi baru bagi dunia pendidikan berbasis digital. Sehingga kecakapan terhadap teknologi dapat terlaksana. 


\section{KESIMPULAN}

Pembelajaran jarak jauh mengharuskan lembaga, perguruan tinggi, dosen, mahasiswa dan seluruh perangkat kampus melakukan inovasi dalam pembelajaran, penggunaan aplikasi seperti zoom, google meet, whatshapp dan google classroom sebagai media pembelajaran jarak jauh dianggap sebagai solusi sementara. Dikarenakan masih banyaknya kendala-kendala yang dialami selama berlangsungnya pembelajaran secara daring. Perlu adanya inovasi digital yang berbasis e-learning yang mampu mengontrol, mengawasi dan meninjau seluruh aktivitas pembelajaran yang dilakukan. Sehingga belajar secara daring mampu di implementasikan semaksimal mungkin dan ilmu yang diajarkan dapat dipahami oleh mahasiswa..

\section{PENGAKUAN}

Riset ditujukan kepada mahasiswa yang sedang melakukan pembelajaran jarak jauh di Sekolah Tinggi Agama Islam Aceh Tamiang (STAI-AT) pada masa pandemi covid 19. Dan ucapan terimakasih yang sebesar-besarnya kepada seluruh informan yang bersedia memberikan tanggapan untuk kelengkapan data-data penelitian ini.

\section{DAFTAR PUSTAKA}

Abidin, Z., Hudaya, A., \& Anjani, D. (2020). Efektivitas Pembelajaran Jarak Jauh Pada Masa Pandemi Covid-19. Research and Development Journal of Education, 1(1), 131. https:// doi.org/10.30998/rdje.v1i1.7659

Ammy, P. M. (2020). Analisis Motivasi Belajar Mahasiswa Menggunakan Video Pembelajaran Sebagai Alternatif Pembelajaran Jarak Jauh (PJJ). Journal of Mathematics Paedagogic (JMP), https:// doi.org/https://doi.org/10.36294/jmp.v5i1.1354

Dian Primasari, I. F. N., \& Zulela, Z. (2021). Kendala Pembelajaran Jarak Jauh (PJJ) Secara Online Selama Masa Pandemik Covid-19 di Sekolah Dasar. JIKAP PGSD: Jurnal Ilmiah Ilmu Kependidikan, 5(1), 64. https:// doi.org/10.26858/jkp.v5i1.16820

Fikri, M., Faizah, N., Elian, S. A., Rahmani, R., Ananda, M. Z., \& Suryanda, A. (2021). Kendala Dalam Pembelajaran Jarak Jauh Di Masa Pandemi Covid19: Sebuah Kajian Kritis. Jurnal Education and Development, 9(1). https:// doi.org/https://doi.org/10.37081/ed.v9i1.2290

Harahap, A. C. P., Harahap, D. P., \& Harahap, S. R. (2020). Analisis Tingkat Stres Akademik Pada Mahasiswa Selama Pembelajaran Jarak Jauh Dimasa Covid-19. Biblio Couns: Jurnal Kajian Konseling Dan Pendidikan, 3(1), 10-14. https:// doi.org/10.30596/ bibliocouns.v3i1.4804

Indrayana, B., \& Ali Sadikin. (2020). Penerapan E-Learning Di Era Revolusi Industri 4.0 Untuk Menekan Penyebaran Covid-19. Indonesian Journal of Sport Science and Coaching, 2(1). 
Jamal, S. (2020). Analisis Kesiapan Pembelajaran E-Learning Saat Pandemi Covid-19 Di SMK Negeri 1 Tambelangan. Paedagoria: Jurnal Kajian, Penelitian Dan Pengembangan Kependidikan, 11(2). https:/ / doi.org/https:/ / doi.org/10.31764/ paedagoria.v11i2.2467

Jatiyasa, I. W. (2022). Pembelajaran Jarak Jauh Pada Masa Pandemi Covid-19 Di Perguruan Tinggi Keagamaan Hindu. Lampuhyang, 13(1), 30-49. https:// doi.org/10.47730/jurnallampuhyang.v13i1.281

Lexy Moleong. (2014). Metodologi Penelitian Kualitatif. PT Remaja Rosdakarya.

Nahdi, K., Ramdhani, S., Yuliatin, R. R., \& Hadi, Y. A. (2020). Implementasi Pembelajaran pada Masa Lockdown bagi Lembaga PAUD di Kabupaten Lombok Timur. Jurnal Obsesi : Jurnal Pendidikan Anak Usia Dini, 5(1), 177. https:// doi.org/10.31004/obsesi.v5i1.529

Sakti, G., \& Sulung, N. (2020). Analisis Pembelajaran Di Masa Pandemik Covid 19 (Literatur Review). Jurnal Endurance: Kajian Ilmiah Problema Kesehatan, 5(3). https:// doi.org/http://doi.org/10.22216/jen.v5i3.5553

Setyawati, D., \& Harun, D. (3 C.E.). Pengembangan Kualitas Pembelajaran Jarak Jauh Di Universitas Katolik Darma Cendika. Budimas: Jurnal Pengabdian Masyarakat, 1(2021). https://doi.org/http://dx.doi.org/10.29040/budimas.v3i1.2307

Sri, \& Husniyatus. (2020). Pembelajaran Online Berbasis Media Google Formulir Dalam Tanggap Work From Home Masa Pandemi Covid-19 Di Madrasah Ibtidaiyah Negeri (MIN) 1 Paser. Jurnal Pendidikan Agama Islam, $7(1), 37$.

Sugiyono. (2016). Metode Penelilitian Kuantitatif, Kualitatif dan RED. Alfabeta.

Sujarwo, S., Sukmawati, S., Akhiruddin, A., Ridwan, R., \& Suharti Siradjuddin, S. S. (2020). An Analysis of University Students' Perspective On Online Learning in The Midst of Covid-19 Pandemic. Jurnal Pendidikan Dan Pengajaran, 53(2), 125. https:// doi.org/10.23887/jpp.v53i2.24964

Sukanto, D. (2020). Pembelajaran Jarak Jauh dengan Media E-learning sebagai Solusi Pembelajaran pada Masa Pandemi Coronavirus Disease 2019 (Covid-19). Syntax Idea, 2(11), 834. https://doi.org/10.36418/syntaxidea.v2i11.679

Supriyatno, T., Susilawati, S., \& Ahdi, H. (2020). E-learning development in improving students' critical thinking ability. Cypriot Journal of Educational Sciences, 15(5), 1099-1106. https:/ / doi.org/10.18844/cjes.v15i5.5154

Syah, R. H. (2020). Dampak Covid-19 pada Pendidikan di Indonesia: Sekolah, Keterampilan, dan Proses Pembelajaran. SALAM: Jurnal Sosial Dan Budaya Syar-I, 7(5). https:// doi.org/10.15408/sjsbs.v7i5.15314

Syaharuddin. (2020). Menimbang Peran Teknologi dan Guru dalam Pembelajaran di Era COVID-19. Menimbang Peran Teknologi Dan Guru Dalam Pembelajaran Di Era COVID-19.

Tobing, D. H. (2016). Bahan Ajar Metode Penelitian Kualitatif. Program Studi Psikologi Fakultas Kedokteran Universitas Udayana.

Zainal, N. H. (2020). Tantangan Kebijakan Pembelajaran Jarak Jauh Di Era Pandemi Covid $19 . \quad$ Pencerahan, 14(2). 
Journal of Education and Teaching Learning (JETL)

Volume 4, Issue 1, January 2022

Page 14-24

http://www.jurnalpencerahan.org/index.php/jp/article/view/31 